\title{
Benthic habitat mapping on the Scotian Shelf based on multibeam bathymetry, surficial geology and sea floor photographs
}

\author{
Vladimir E. Kostylev ${ }^{1, *}$, Brian J. Todd ${ }^{2}$, Gordon B. J. Fader ${ }^{2}$, R. C. Courtney ${ }^{2}$, \\ Gordon D. M. Cameron ${ }^{3}$, Richard A. Pickrill ${ }^{2}$ \\ ${ }^{1}$ EcoVector, 215 Oceanview Drive, Bedford, Nova Scotia B4A 4G9, Canada \\ ${ }^{2}$ Geological Survey of Canada (Atlantic), PO Box 1006, Dartmouth, Nova Scotia B2Y 4A2, Canada \\ ${ }^{3}$ Cameron Geoscience Research, 55B Kennedy Drive, Dartmouth, Nova Scotia B2X 1N6, Canada
}

\begin{abstract}
This study presents results of a new approach for sea floor habitat mapping based on an integrated analysis of multibeam bathymetric data, associated geoscientific information, and benthos data from Browns Bank on the southwestern Scotian Shelf, off the Canadian Atlantic coast. Based on sea floor sediment maps and statistical analysis of megabenthos determined from photographs, 6 habitats and corresponding associations of benthos were derived and mapped. The habitats are distinguished primarily on the basis of sediment type and water depth. Additional factors are sea floor geomorphology, habitat complexity, and relative current strength. A Browns Bank benthic habitat map is developed as a conceptual model summarizing the understanding of the bank ecology. This study highlights the utility of multibeam bathymetric sonar for interpretation of sea floor sediments and for extrapolating benthic habitat characteristics across large areas of sea floor.
\end{abstract}

KEY WORDS: Habitat mapping $\cdot$ Benthos $\cdot$ Multibeam $\cdot$ Sediment $\cdot$ Scotian Shelf

\section{INTRODUCTION}

The problem

Mapping sea floor habitat is the fundamental first step necessary for scientific fisheries management, for monitoring environmental change and for assessing the impact of anthropogenic disturbance on benthic organisms. Benthic habitat is primarily determined by substrate type (sediment or rock), which reflects past and present physical processes in the near-bottom environment. The substrate determines to a large extent the presence or absence of a particular benthic species and modifies the effect of disturbance on the benthic community (Greene et al. 1995, Auster \& Langton 1999).

\footnotetext{
*E-mail: kostol@agc.bio.ns.ca
}

Traditionally, geoscientific sea floor mapping primarily involved the identification of sediment type, distribution, and thickness based on the combination of remotely sensed geophysical data (sidescan sonar and seismic reflection profiling) and sea floor sediment sampling. The advent of multibeam sonar technology in the last decade, providing $100 \%$ sea floor coverage, has revolutionized geological mapping (Courtney \& Shaw 2000). Multibeam data and derived images reveal previously unrecognized sea floor morphological and sediment textural attributes. This new generation of bathymetric and geological maps provides a framework for mapping the distribution of benthos. This paper presents an interdisciplinary habitat mapping study based on analysis of megabenthos (organisms larger than $1 \mathrm{~cm}$ in linear dimensions) identified from sea floor photographs integrated with an interpretation of multibeam bathymetric data and associated geoscientific information. The biological objectives are to 
discriminate distinct assemblages of megafauna benthic species, to understand and correlate the relationship between sea floor surficial sediments and biota, and to classify and map the defined benthic habitats.

Habitat is commonly defined as a place where a microorganism, plant or animal lives (Begon et al. 1996). Traditionally the word 'habitat' implied a set of associated environmental descriptors (e.g. substrate, temperature, salinity). The characterization of habitat requires definition of spatial boundaries and limits of physical factors pertaining to a particular organism or groups of organisms that share environmental preferences and occupy the same habitat type, for example rocky shore habitat, mud flat habitat, etc. Therefore our working definition of a habitat is a spatially defined area where the physical, chemical, and biological environment is distinctly different from the surrounding environment. We base habitat mapping on the assumption that organisms distribute themselves along environmental gradients and that their clusters define distinct sets of environmental factors. Discrimination of benthic assemblages and definition of significant physical factors is achieved with cluster analysis, ordination, and similarity analyses. A description of each habitat is given together with the description of the associated benthic assemblage.

\section{The setting of Browns Bank}

Browns Bank is located at the southwestern end of the Scotian Shelf at the eastern entrance to the Gulf of Maine, approximately $100 \mathrm{~km}$ south of Yarmouth, Nova Scotia (Fig. 1). On the regional nautical chart, the morphology of the bank appears as 2 flat plateaus, with water depths ranging from $<50 \mathrm{~m}$ in the western area to almost $100 \mathrm{~m}$ in the east (Canadian Hydrographic Service 1988). The southwestern edge of Browns Bank drops abruptly to the Northeast Channel (>200 m), which is a major trough separating Browns Bank and Georges Bank and acts as the principal hydrodynamic connection between Scotian Slope water and the Gulf of Maine. Browns Bank is bounded to the north by a rough-floored bedrock channel with water depths $>100 \mathrm{~m}$.

Ocean circulation in the region of Browns Bank has been studied using moored current metres, drifting buoys, and finite element modeling (Smith 1983, Page \& Smith 1989, Lynch \& Naimie 1993, Hannah et al. 2000). A permanent clockwise gyre exists on Browns Bank with current strengths up to $20 \mathrm{~cm} \mathrm{~s}^{-1}$. Along the northern edge of the bank, circulation is aligned from west to east. Along the south edge of Browns Bank, adjacent to the Northeast Channel, currents are strongly aligned from southeast to northwest, parallel to the bank flank. On the bank, the dominant current direction varies within the gyre and can be inferred from sand wave and other bedform orientations.

The Scotian Shelf is a formerly glaciated continental shelf characterized by a series of large, shallow banks on the outer shelf, of which Browns Bank is one example (Fig. 1). The banks are separated by intervening saddles or troughs. These landforms are interpreted as cuestas and juxtaposed lowlands developed on the bedrock surface and are typical of a coastal plain environment affected by subaerial erosion in the Late Tertiary period (King \& MacLean 1976). The coastal plain was modified by the advance and retreat of North American continental ice sheets during the Quaternary period (the last advance culminating at $20000 \mathrm{BP}$ ) (King \& Fader 1986). Further modification took place during the low stand of Late Wisconsinan sea level $(\sim 18000$ BP $)$ at $\sim 120 \mathrm{~m}$ below present sea level and the subsequent transgression across the shelf of rising sea level (Drapeau \& King 1972, Fader et al. 1977, Fader 1989).

Early geological mapping of surficial sediments on Browns Bank identified 2 facies of the Sable Island Sand and Gravel formation (Drapeau \& King 1972, Fader et al. 1977). Gravel dominated in the east and sand to the west, but details of textural characteristics and bedforms were not revealed by early studies. This formation is underlain by the Emerald Silt formation, a glaciomarine muddy sediment. The present knowledge of surficial sediment distribution provided by multibeam data provides considerable detail on sediment distribution of the Sable Island Sand and Gravel formation together with information on bedforms and sediment transport pathways.

\section{METHODS}

Multibeam bathymetric data. Multibeam bathymetric data were collected by the Canadian Hydrographic Service on Browns Bank in 1996 and 1997 using the Canadian Coast Guard Ship (CCGS) 'Frederick G. Creed' equipped with a Simrad EM1000 multibeam bathymetric system. This system produces 60 beams arrayed over an $\operatorname{arc}$ of $150^{\circ}$ and operates by ensonifying a narrow strip of sea floor across track, and detecting the bottom echo with narrow, across-track, listening beams. The swath of sea floor imaged on each survey line was 5 to 6 times the water depth. Line spacing was about 3 to 4 times water depth to provide ensonification overlap between adjacent lines. The Differential Global Positioning System was used for navigation, providing positional accuracy of $\pm 3 \mathrm{~m}$. Survey speeds averaged 14 knots resulting in an average data collection rate of about $5.0 \mathrm{~km}^{2} \mathrm{~h}^{-1}$ in water depths of 35 to $70 \mathrm{~m}$. 
Fig. 1. Location map of Browns Bank on the western Scotian Shelf. Isobaths are in $\mathrm{m}$. The white area with dashed boundary on Browns Bank is the area of the multibeam image in Fig. 2

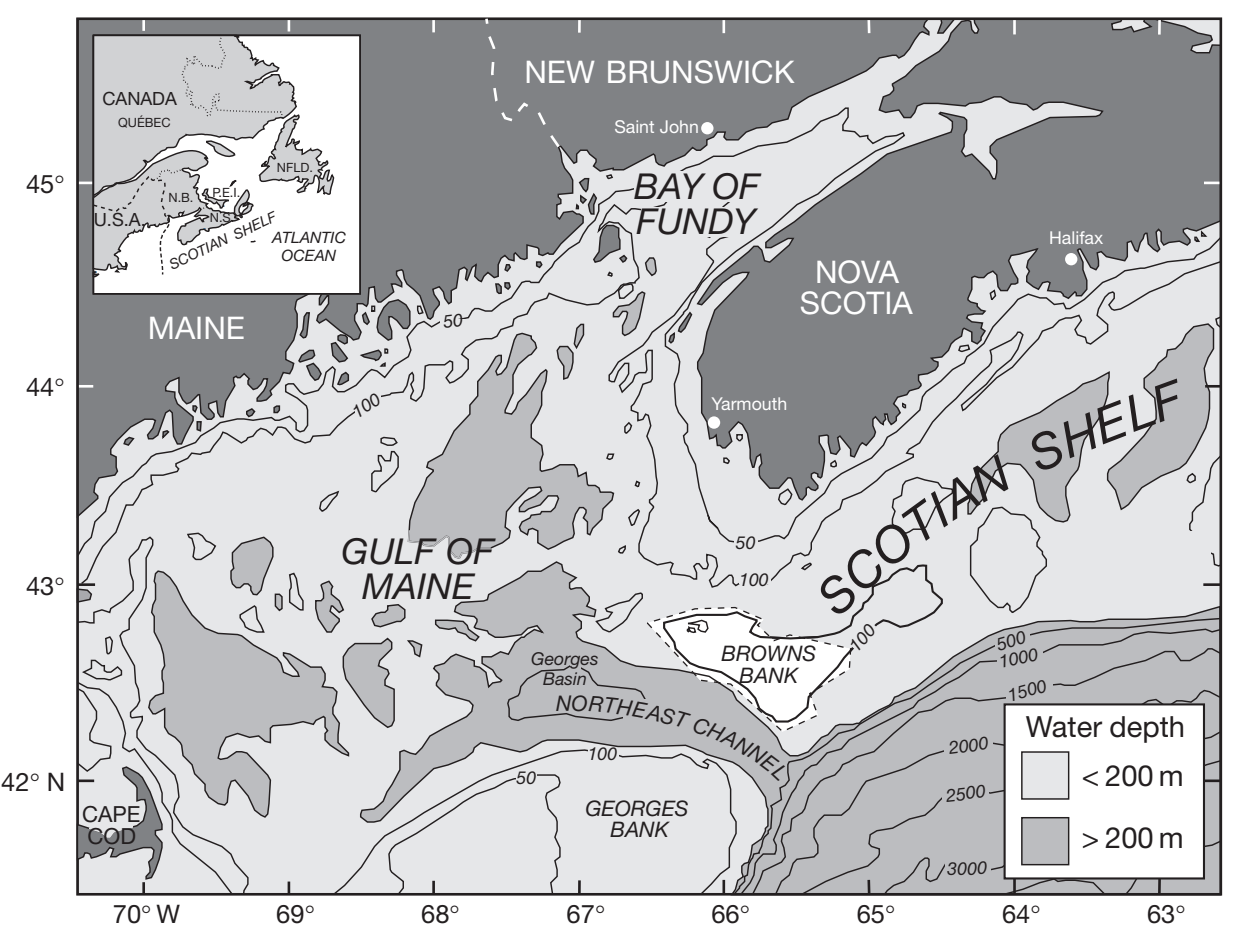

During the survey, water depth values were inspected, and erroneous values were removed using CARIS/HIPS (Hydrographic Information Processing System) software from Universal Systems Limited, Fredericton, New Brunswick. Within HIPS, the data were adjusted for tidal variation using tidal predictions from the Canadian Hydrographic Service. The data were archived in the form of 'raw' datagrams on Exabyte tapes. Multibeam bathymetric data were extracted from the datagrams and were gridded in $10 \mathrm{~m}$ (horizontal) bins and shaded with artificial illumination using software developed by the Ocean Mapping Group at the Geological Survey of Canada (Atlantic). Relief maps, colour-coded to depth, were developed and displayed on a Hewlett-Packard workstation using GRASS (Geographic Resources Analysis Support System) developed at the US Army Construction Engineering Research Laboratories; this software is in the public domain. The resulting image of Browns Bank is displayed in Fig. 2.

In addition to the bathymetric data, backscatter strengths ranging from 0 to -128 decibels (dB) were
Fig. 2. Multibeam bathymetric map of Browns Bank. Artificial sun illumination of the digital terrain model is from the northeast at an angle of $45^{\circ}$ above the horizontal. The vertical exaggeration is $10 \times$. A colour palette has been applied to the bathymetric data; warm colours represent shallow water and cool colours deep water. The faint banding on the image is an artefact of both the ship's survey track during data collection and data processing

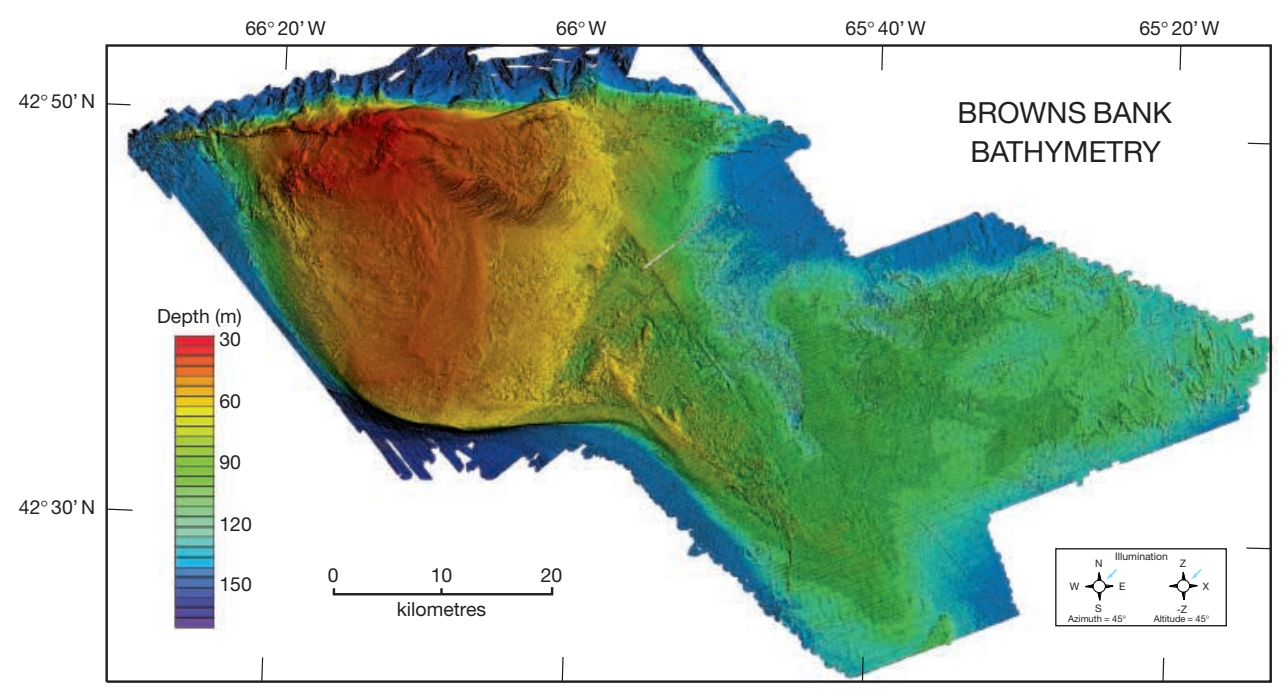


logged by the Simrad EM1000 system (see Urick [1983] and Mitchell \& Somers [1989] for backscatter definition). To reduce the dynamic range of the recorded data, the system applies a partial correction to the backscatter strength values for the varying angle of incidence by using Lambert's law for the variation with angle and assuming a flat sea floor (Simrad 1992). Backscatter strengths are computed using calibration values for the electronics and transducers at the time of instrument manufacture (Mitchell 1996). Unless further calibration occurs at the time of survey, backscatter strength values may be inaccurate. However, the relative signal is still useful and differences in the backscatter between different sea floor materials are clearly visible in the data. High backscatter values (dark tones) are typically -10 to $-30 \mathrm{~dB}$ for gravel and low backscatter values (light tones) range from -30 to $-60 \mathrm{~dB}$ for fine-grained sand (Mitchell \& Hughes Clark 1994, Shaw et al. 1997). Because backscatter is a function of a suite of acoustical variables, it is prudent to interpret backscatter images in conjunction with other geophysical data (seismic reflection and sidescan sonar sonograms) and geological samples of sea floor materials. For comparison with the bathymetric image (Fig. 2), Browns Bank backscatter data were processed and displayed (Fig. 3). The amplitude of the returned signal varies from -16 to $-40 \mathrm{~dB}$, highlighting aspects of geological features not apparent in the bathymetric image.

Geoscientific data. To complement the multibeam survey, $850 \mathrm{~km}$ of high-resolution geophysical profiles were collected over Browns Bank in 1998. The systems deployed included a Huntec Deep Tow Seismic (DTS) boomer, single-channel sleeve-gun seismic reflection, and Simrad MS992 sidescan sonar (120 and $330 \mathrm{kHz}$ ). The geophysical survey investigated different sea floor types and features identified using the multibeam bathymetric and backscatter data (Fig. 4).

Using an $0.75^{3} \mathrm{~m}$ Institutt for Kontinentalsokkelundersøkelser (IKU) grab, 24 sea floor sediment samples were collected at strategic sites interpreted from geophysical profiles (Fig. 4). The sites were chosen to collect sea floor sediment samples representative of broad areas sharing similar geomorphology (based on the bathymetric image) and acoustic backscatter response. Also, the selected sites were located along geophysical profiles to provide detailed geological control in the third dimension. The grab sampler penetrated the sea floor up to $0.5 \mathrm{~m}$ and preserved the integrity of the layering within the surficial sediments. Grain size descriptions based on the samples and on sea floor photographs adhere to the Wentworth size class scheme for clastic sediments (Wentworth 1922).

Sea floor photographs. With locations chosen from the multibeam bathymetric data and the geophysical profiles, 26 sea floor photographic sites were occupied in 1998, of which 21 were occupied by a single-image camera (207 photographs) and 5 by a stereo camera (98 photographs) (Fig. 4). The single-image camera system consisted of a box-shaped aluminum frame supporting a Benthos Deep Sea Survey camera (model 377) and an Edgerton Deep Sea flash (model 383). The system was triggered by a weight suspended $1 \mathrm{~m}$ below the frame providing images of approximately $1.2 \times 0.8 \mathrm{~m}$ of the sea floor. The stereo camera system consisted of a tripod-shaped aluminum frame supporting two $35 \mathrm{~mm}$ Pentax SF-10 cameras, each fitted with $50 \mathrm{~mm}$ lens, and a $50 \mathrm{~W}$ light source. An instrument-mounted computer and bottom-sensing switch controlled the cameras. The stereo camera images recorded approximately $0.36 \times 0.55 \mathrm{~m}$ of the sea floor.

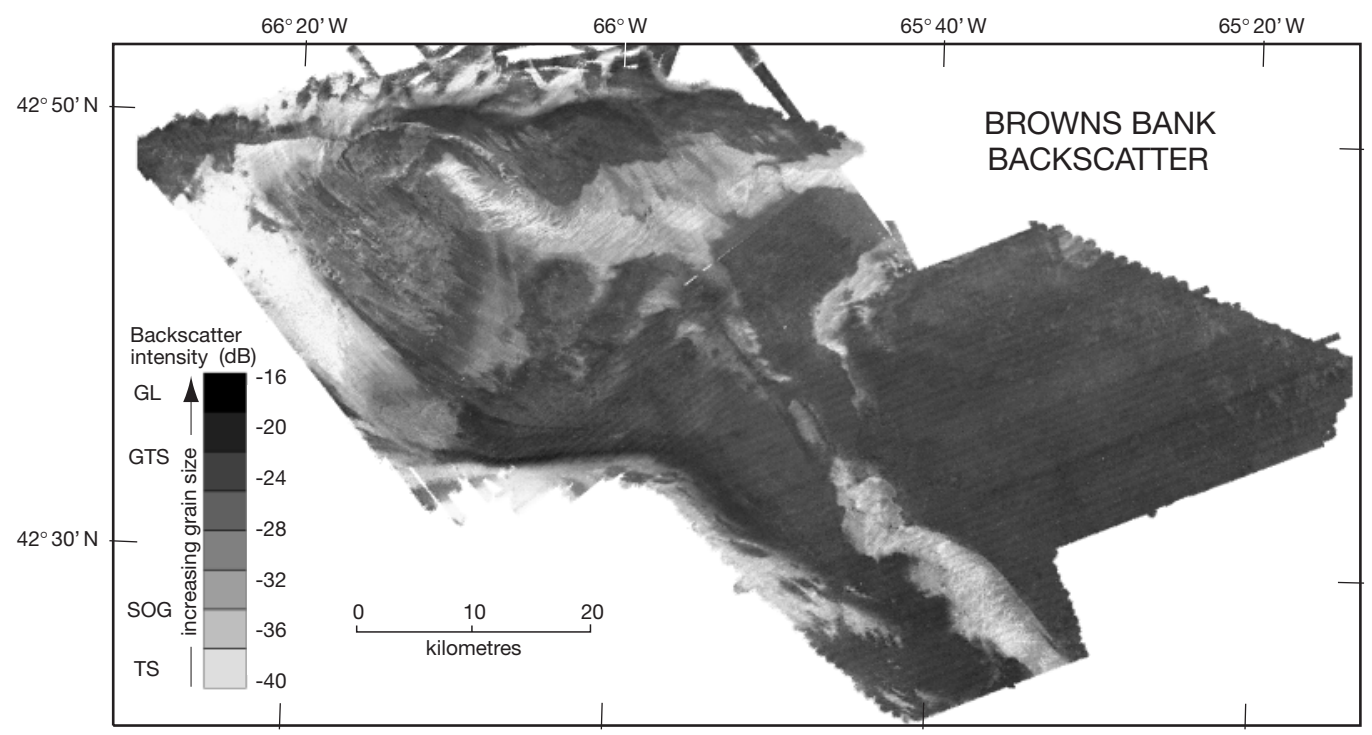

Fig. 3. Backscatter map of Browns Bank. High backscatter values (dark tones) are interpreted as gravel and low backscatter values (light tones) are interpreted as sand. As in Fig. 2, faint artefact banding is visible. Bedforms and their orientations are, in many areas, enhanced by the pattern of contrasting backscatter intensities 
Fig. 4. Interpretation of distribution of surficial sediment type, thickness and bedforms on Browns Bank. Geophysical survey tracks are shown by black lines; sea floor photograph stations are indicated by white squares and IKU grab stations by yellow squares. The white outline box on northwestern Browns Bank identifies the area described in Fig. 5

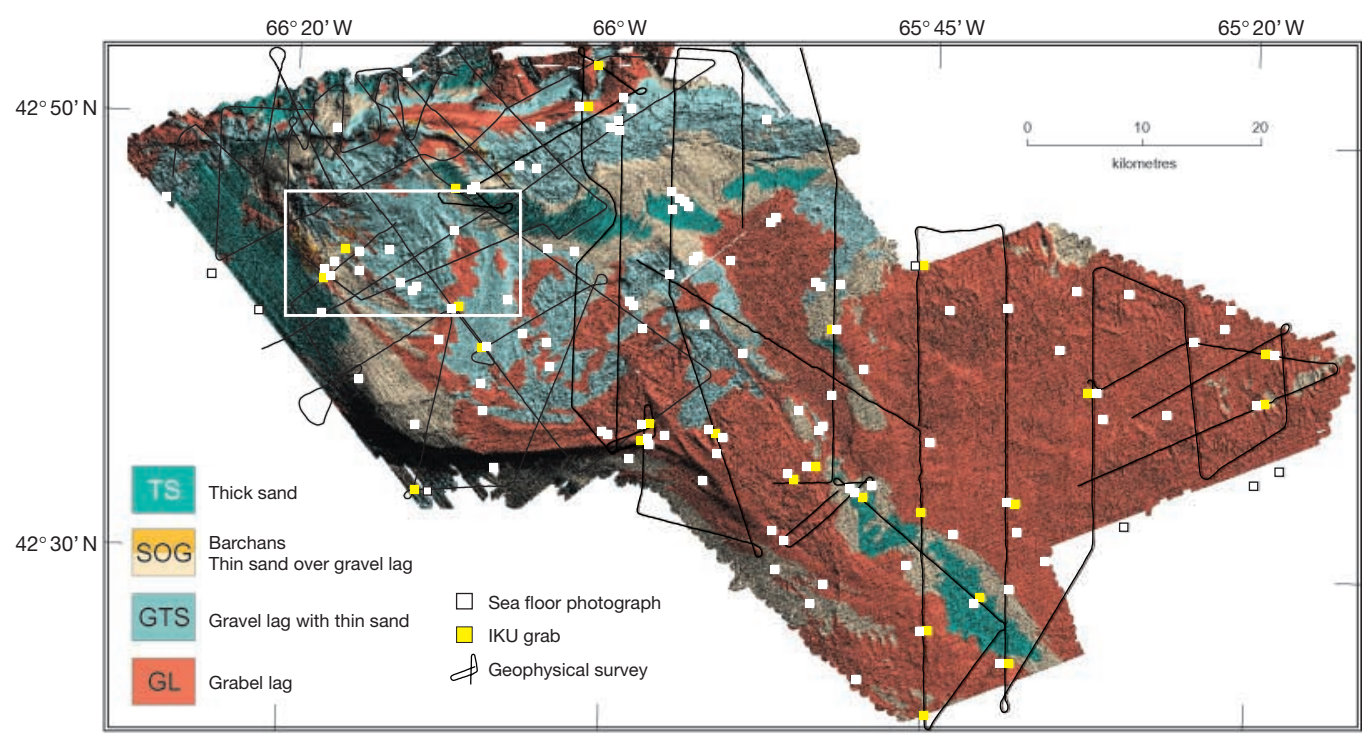

The 1998 set of sea floor photographs was augmented by 515 single and stereo photographs collected at 90 stations on Browns Bank by the Department of Fisheries and Oceans Canada (DFO) in 1984 and 1985. These images recorded from $0.76 \times 0.51 \mathrm{~m}$ to $1.05 \times$ $0.71 \mathrm{~m}$ of the sea floor. Details of this camera system are given in Wildish et al. (1990), and locations of the photographs from all years are indicated in Fig. 4. All photographs were digitized in Kodak Photo CD format on compact discs, and analyzed on a computer screen. Image sharpness, contrast, brightness and color balance were computer-enhanced using Paint Shop Pro 5.01 (Jasc Software, Inc).

Megafauna and habitat identification. Identification of benthic fauna to the lowest possible taxonomic level, as well as geological description, was undertaken for the camera stations and the sediment samples. Subsamples of the grab samples were sieved through a $1 \mathrm{~mm}$ mesh sieve and analyzed for the presence or absence of species in order to augment the identification of fauna from sea floor photographs. Frequency of occurrence was calculated for each photographic station by dividing the number of photographs in which a species was present by the number of photographs taken at a station. Species were grouped into major taxa. Cirripedia and Nudibranchia were omitted due to their rarity, leaving 22 groups that were used in further analyses. The taxonomic level of each group was chosen on the basis of similarity of habitats and life history traits of benthic organisms. For example, the sea cucumbers Cucumaria frondosa and Psolus fabricii were analysed as 2 separate groups due to different habitat preferences. Taxonomic diversity for each station was calculated as the average number of major groups per photograph. The average abundance of benthic spe- cies and the percent cover of sponges were calculated for each station from the 1998 photographs.

The relative sea floor cover of boulders (>256 mm), gravel (2 to $256 \mathrm{~mm})$, sand ( 0.0625 to $2 \mathrm{~mm}$ ) and shell hash was estimated from each photograph. Also, the presence of 5 types of burrows, 2 types of trails, tracks, scallop pits, and siphons were recorded. A total score for bioturbation was given as a normalized ratio ( 0 to 100) of the number of observed feature types to the maximum possible number of feature types. The presence of fine-grained sediments was ranked on a scale from 0 (none) to $100 \%$ (very abundant).

Statistical analysis. A total of 115 photographic stations and 24 grab stations were studied. All statistical analyses refer to photographic stations unless stated otherwise. Principal components analysis (PCA) was performed with normalized varimax rotation on standardized frequencies of occurrence of major taxa. One-way analysis of variance (ANOVA) was used for analyses of variability among stations in PCA factor scores versus sediment type and water depth on taxonomic diversity. Four levels of the factor 'sediment type' were used, as identified from multibeam interpretation. The homogeneity of variances was tested using Cochran's C-test. Student-Newman-Keuls (SNK) tests were performed for the post-hoc analysis of the difference between means. Analysis of covariance (ANCOVA) was used to test the effects of sediment type and water depth on taxonomic diversity. Covariate 'depth' was included in this analysis because it covers a broad range of depths with satisfactory replication of depths for different sediment types. Cluster analysis of species associations was performed using a Pearson correlation matrix for standardized frequencies of occurrence of major taxa identified in the photo- 
graphs. Jaccards' similarity matrix was used for the analysis of the IKU grab data. In both cases clustering was performed using the complete linkage amalgamation technique.

Dissimilarity analysis was performed based on BrayCurtis dissimilarity among stations with respect to species, and dissimilarities among stations based on all possible combinations of 5 physical factors: depth, average yearly temperature, sediment type (coded from 1 to 4 based on the proportion of sand), variance of temperature based on the 4 seasons, and average nearbottom current strength. All variables were normalized prior to construction of dissimilarity matrices. The resulting correlation coefficients (Spearman's rho) were ranked, and the highest correlation was considered indicative of the combination of variables that best defined community structure (Clarke \& Ainsworth 1993).

In order to examine the influence of sediment type on the diversity of megabenthos, 2 types of data were analysed using 1-way ANOVA: the average number of major taxonomic groups per station, and the average number of distinguished species. Statistical analyses were performed using Statistica ${ }^{\mathrm{TM}}$ software.

\section{RESULTS}

\section{Surficial geology}

Based on the geophysical data and the sea floor sediment characteristics, 4 facies of the Sable Island
Sand and Gravel formation were mapped (Fig. 4, Table 1): thick sand (TS), sand over gravel lag (SOG), gravel lag with thin sand (GTS), and gravel lag (GL) (Todd et al. 1999). Sand deposits in a variety of bedforms are superimposed on the widespread GL that covers the bank. The morphology and extent of the sand deposits are interpreted from the bathymetric image (Fig. 2) and from the backscatter image, on which the light-toned areas are interpreted as sand (Fig. 3); sea floor sediment samples and sidescan sonograms confirm this interpretation (Todd et al. 1999). The sand deposits are discontinuous on the GL and range in thickness from centimetres up to $10 \mathrm{~m}$. Bedform morphology suggests that the sand deposits are presently active and have developed in response to the clockwise circulation of water around Browns Bank. For example, on western Browns Bank adjacent to the Northeast Channel, currents are strongly aligned to the northwest (Fig. 5). Here, an aerially extensive sheet of sand reaches a thickness of $6.5 \mathrm{~m}$ and takes the form of sand waves, which are flowtransverse, constructive bed features (Amos \& King 1984). The sand wave amplitude is $\sim 1 \mathrm{~m}$ and the average wavelength is $\sim 40 \mathrm{~m}$. In contrast, the sand waves in shallower water near the centre of the bank, shown in the upper right of the panels in Fig. 5, are $\sim 10 \mathrm{~m}$ from trough to crest with an average wavelength of $180 \mathrm{~m}$. These latter bedforms exhibit an asymmetric cross-section with the steeper lee faces oriented southeast indicating net sand transport in that direction.

Table 1. Benthic habitats interpreted from sea floor photographs and surficial sediments. TS: thick sand, SOG: sand over gravel lag, GL: gravel lag, GTS: gravel lag with thin sand

\begin{tabular}{|c|c|c|c|c|c|}
\hline $\begin{array}{l}\text { Substrate } \\
\text { type }\end{array}$ & Habitat & $\begin{array}{l}\text { Habitat } \\
\text { complexity }\end{array}$ & $\begin{array}{l}\text { Relative current } \\
\text { strength }\end{array}$ & $\begin{array}{l}\text { Water depth } \\
(\mathrm{m})\end{array}$ & $\begin{array}{l}\text { Benthic/biological } \\
\text { association }\end{array}$ \\
\hline Sand & (1) Shallow water & Low & High & $<50$ & Barren \\
\hline TS and SOG & (2) Deep water & Low & Low? & $>100$ & $\begin{array}{l}\text { Barren, with solitary hydroids } \\
\text { and sand dollars (Echinarachinus parma) }\end{array}$ \\
\hline \multirow[t]{6}{*}{$\begin{array}{l}\text { Gravel } \\
\text { GL and GTS }\end{array}$} & $\begin{array}{l}\text { (3) Soft coral and sea } \\
\text { cucumber }\end{array}$ & Moderate & High & $<50$ & $\begin{array}{l}\text { Alcyonacea-Cucmaria association } \\
\text { Low species diversity and abundance }\end{array}$ \\
\hline & (4) Scallop & Moderate & High & $40-100$ & $\begin{array}{l}\text { Placopecten magellanicus and } \\
\text { associated species }\end{array}$ \\
\hline & & & & & $\begin{array}{l}\text { Low macrobenthos diversity } \\
\text { and abundance }\end{array}$ \\
\hline & (5a) Terebratulina & High & Moderate & $90-120$ & $\begin{array}{l}\text { Terebratulina community } \\
\text { High macrobenthos diversity and } \\
\text { abundance }\end{array}$ \\
\hline & (5b) Terebratulina subtype & High & Low & $>100$ & $\begin{array}{l}\text { Sponge-dominated community, } \\
\text { Terebratulina subtype }\end{array}$ \\
\hline & (6) Deposit-feeder & Low & Low & $>100$ & $\begin{array}{l}\text { Deposit-feeder community } \\
\text { High abundance of deposit-feeding } \\
\text { polychetes }\end{array}$ \\
\hline
\end{tabular}



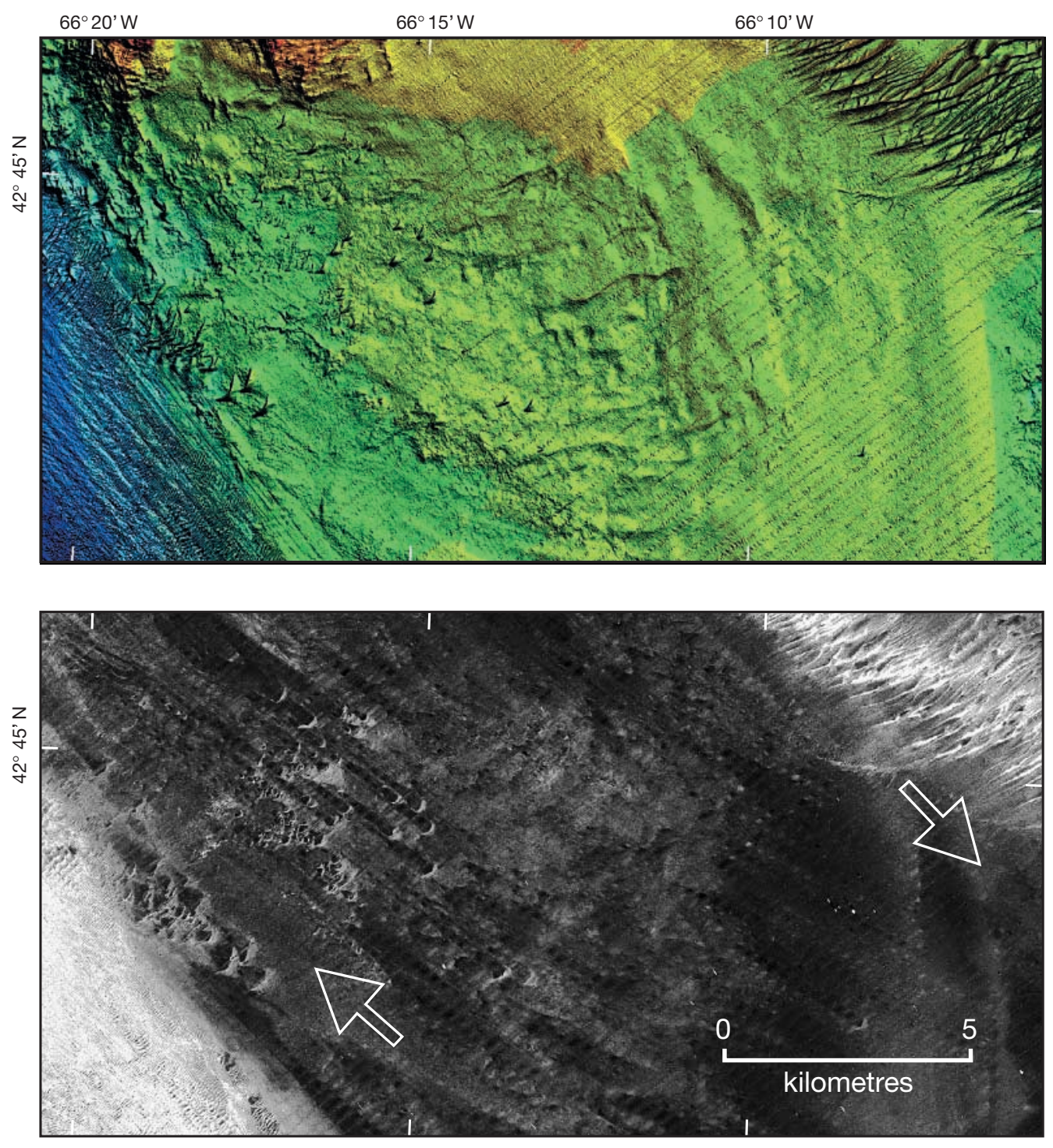

Fig. 5. Area of northwestern Browns Bank (Fig. 4) showing bathymetry (upper), backscatter (middle) and geological interpretation (lower). The backscatter intensity scale is the same as in Fig. 3, and the geological descriptions are the same as in Fig. 4. The colourcoded bathymetry does not correspond to the scale of Fig. 2; the colour distribution here has been optimized for the depth range of $35 \mathrm{~m}$ (upper left, warm colours) to $100 \mathrm{~m}$ (lower left, cool colours). The arrows on the backscattter image (middle) show the direction of dominant current flow

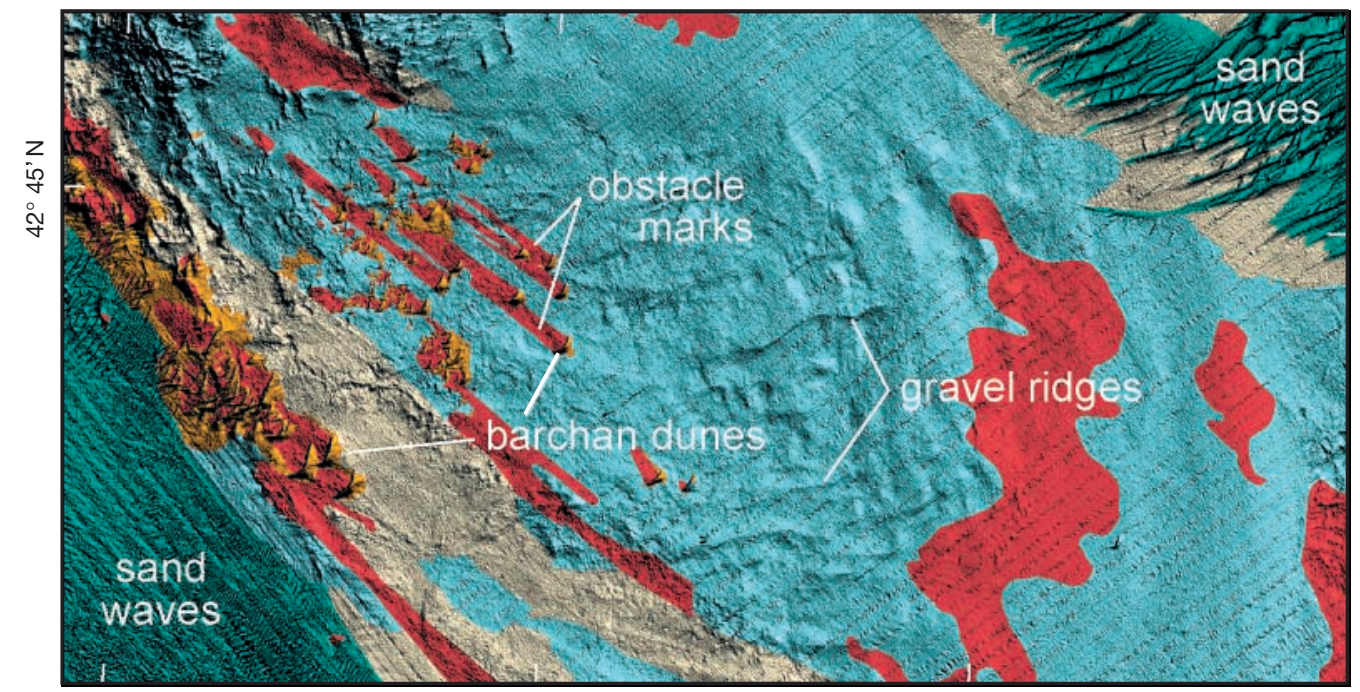

$66^{\circ} 20^{\prime} \mathrm{W}$

$66^{\circ} 15^{\prime} \mathrm{W}$ 
The sea floor between these 2 sand wave fields has a 'streaky' linear appearance in the backscatter image (Fig. 5, middle), and is interpreted as thin, discontinuous ribbons of sand overlying GL. Barchan dunes, which are crescent-shaped in plan view, are prominent in the west, reaching heights of 6 to $7 \mathrm{~m}$ with crescent widths of $400 \mathrm{~m}$. The barchans are convex to the southeast with steep lee faces to the northwest, indicating dominant current flow in the latter direction. These bedforms disrupt current flow and affect the transport and deposition of sand across the sea floor to the northwest. 'Tails', or obstacle marks, in some instances kilometres in length, emanate from the lee (concave) faces of the barchan dunes, once again clearly indicating net bottom-flow current direction to the northwest. These obstacle marks appear as dark bands on the backscatter image (Fig. 5, middle), compared with the surrounding low backscatter values, and represent a lack of sand deposition and exposure of GL on the sea floor. This suggests that zones of higher energy and turbulence are generated by the barchan dunes which persist for distances over $2 \mathrm{~km}$ beyond the dunes (cf. studies on land summarized by Lancaster 1987).

The widely distributed GL on Browns Bank developed from glacial till which was reworked during the transgression of rising sea level across the Scotian Shelf after about 18000 BP (Drapeau \& King 1972, Fader et al. 1977, Fader 1989). The GL exhibits a wide variation in grain sizes: IKU grab samples contained grain sizes up to $1000 \mathrm{~mm}$, and photographs and sidescan sonar records imaged abundant cobbles (64 to $256 \mathrm{~mm})$ and boulders $(>256 \mathrm{~mm})$. Sand $(0.0625$ to $2 \mathrm{~mm}$ ) was present in every GL sample as well. On the eastern, deeper part of Browns Bank, sea floor photographs showed a thin layer of fine-grained sediment covering the GL. The IKU grab samples from the eastern bank reflect this observation with silt (0.0039 to $0.0625 \mathrm{~mm}$ ) constituting up to $4 \%$ of individual sediment samples.

\section{Distribution of megabenthos}

The general trend of the distribution of benthic megainvertebrates on Browns Bank shows a predominance of suspension-feeders (e.g. Placopecten, Cucumaria, Sabellidae) on the western, shallower part of the bank and an increase in abundance of depositfeeders (e.g. Nothriidae) with increasing depth toward the east (Fig. 6). The shallower part of the bank is commonly populated by sea scallops (Placopecten magellanicus), sea cucumbers (Cucumaria frondosa), and soft corals (Alcyonacea). No megafauna was observed on large sand bedforms. Structurally complex gravel habitats (i.e. exhibiting a wide grain size variability) on the central and eastern parts of the bank are the most diverse and have the greatest abundance of sessile epifauna. Several species of sponges (notably Halichondria panicea, Myxilla sp. and Cliona sp.), brachiopods (Terebratulina septentrionalis) and tunicates (Molgulidae spp.) are characteristic of these areas. Some sediments contain fine-grained fractions of silt and clay, which are trapped in crevices and depressions among boulders and other gravel. On the central part of the bank, Sabellid polychaetes and sea cucumbers (Psolus fabricii) are common and abundant, and multiple burrows and siphons of infaunal invertebrates are seen among the rocks. A fine meshwork of the polychaete Filograna implexa tubes is frequent on gravel in this area. Sediments on the deeper part of the bank $(>100 \mathrm{~m})$ display a thin layer of mud. Leafy bryozoans (Flustra foliacea), sponges, and ascidians dominate at these depths. Deposit-feeding polychaetes (Nothriidae and Terebellidae) are common on finegrained sediments and are most abundant along the deeper, eastern edge of the bank. Areas of sand within this area are usually barren with solitary hydroids (Corymorpha pendula) and sand dollars as typical representatives of megafauna.

Cluster analysis was performed in order to distinguish associations between major benthic taxa as identified from bottom photographs. Three main groups of taxa and several close associations can be distinguished (Fig. 7). The upper group (Hydroidea, Asteroidea, Porifera, Sabellidae, Serpulidae, Ascidiacea and Brachiopoda) exhibits the closest association and is composed of species commonly found on complex gravel substrates. The cluster of Scaphopoda, Bryozoa and Macrura is less closely associated with this group because these taxa are less common. The middle cluster (solitary hydroids, Actiniaria, Psolus, Terebellidae, Nothriidae, Echinoidea, Ophiuroidea) represents taxa commonly found in deeper, less hydrodynamically active parts of the bank, on sand or fine-grained sediments. The lower cluster (Gastropoda, Paguridae, Placopecten, Alcyonacea, Holothuroidea) pools taxa common on the shallower, western part of the bank, and the first three of this cluster are typical for GL. Within the larger clusters several close associations of taxa (Asteroidea and Porifera, Ascidiacea and Brachiopoda and Alcyonacea and Holothuroidea) are ecologically meaningful and important for further discussion.

\section{Sediment-benthos relationships}

Analysis of variance showed the significant control of sediment type on species richness, with a markedly higher average number of species found in areas of GL, and lowest species diversity on TS (ANOVA, 

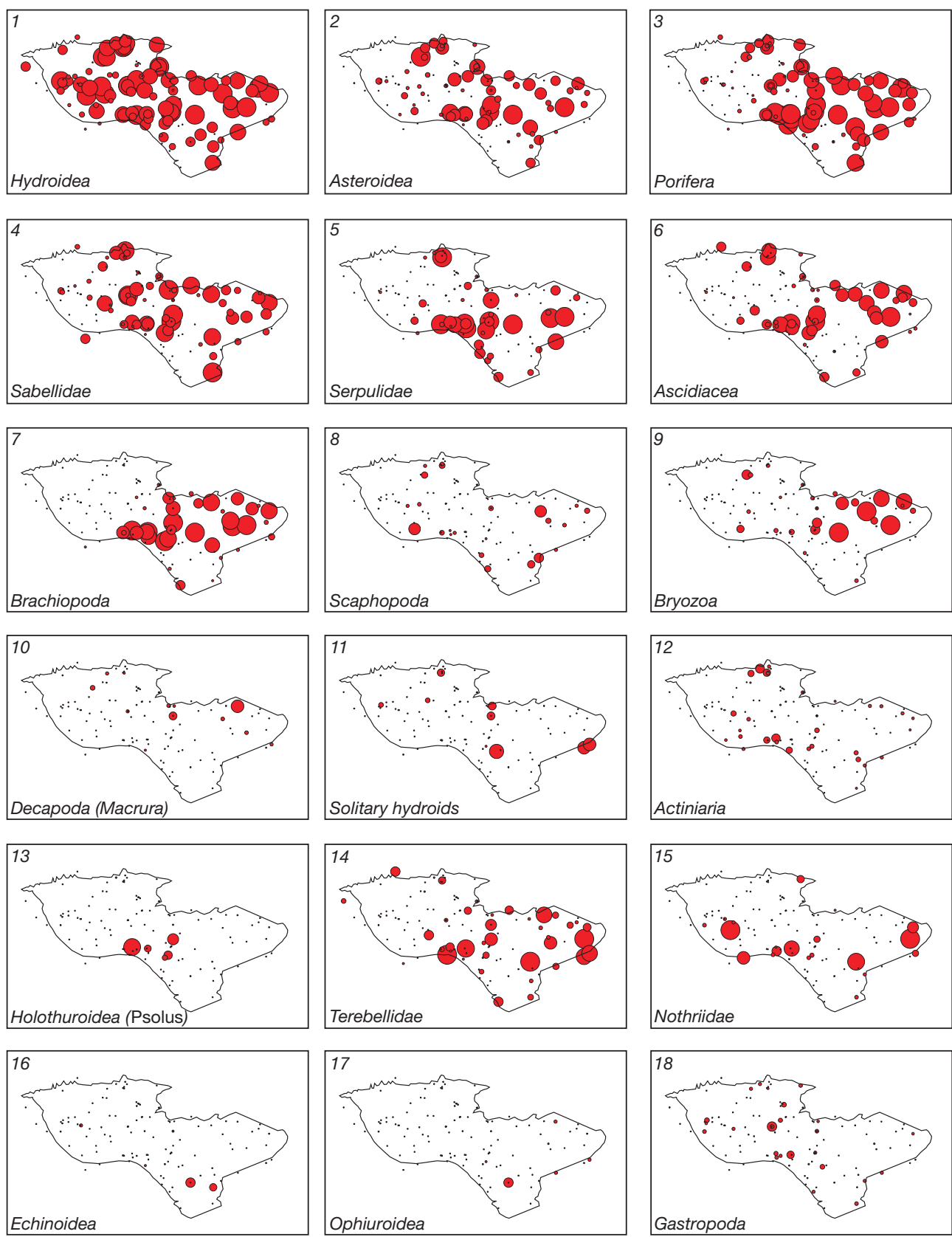

Fig. 6. Distribution of major taxa of megabenthos (Panels 1-22) and taxonomic diversity (Panel 23) on Browns Bank (outlined by the $100 \mathrm{~m}$ isobath) as identified from bottom photographs. For each benthic taxon, the circle size represents its frequency of occurrence. Larger circles correspond to higher values
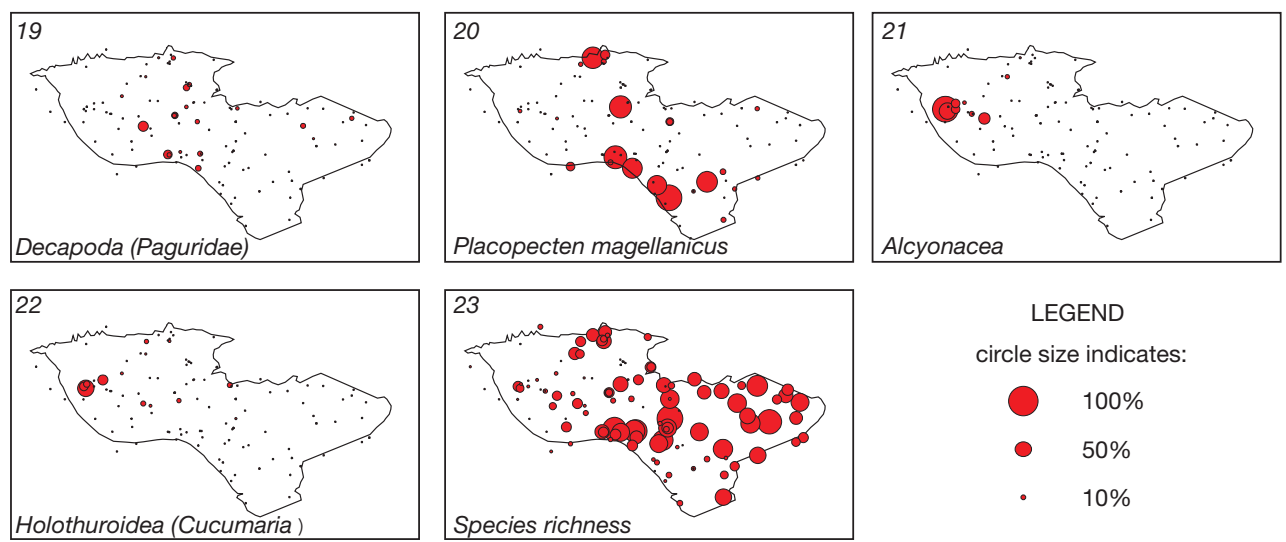

LEGEND

circle size indicates:

$$
\begin{array}{cc}
\text {. } & 100 \% \\
\hline & 50 \% \\
\text { - } & 10 \%
\end{array}
$$




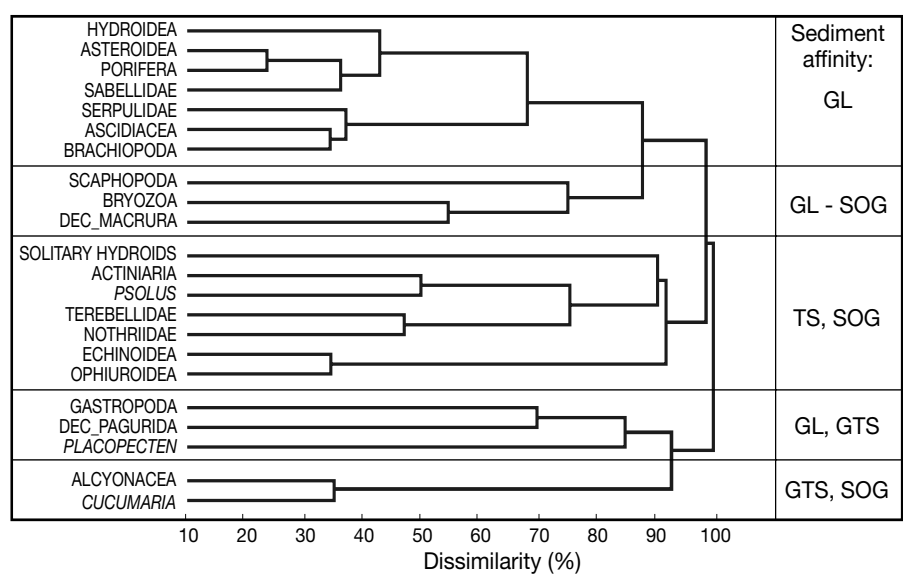

Fig. 7. Cluster analysis of the frequencies of occurrence of major taxa as identified from bottom photographs. Affinity of taxa for sea floor sediment type is indicated. Sediment types are gravel lag (GL), sand over gravel (SOG), thick sand (TS), and gravel with thin sand (GTS)

df $=3 / 111, F=5.574, p=0.006 ;$ Cochran's $C=0.600$, $\mathrm{p}=0.321$ ). The SNK test shows that diversity on TS is significantly lower than diversity on other sediment types. This relationship is also apparent at a lower taxonomic level of resolution. ANCOVA shows that sediment type has a significant effect on the number of higher taxonomic groups (df $=3 / 111, F=12.298$, $p<$ 0.0001). Covariate depth was not significant $(\mathrm{p}=0.0848)$ and there was no significant interaction between depth and sediment type. Variances, however, were heterogeneous (Cochran's $C=0.433$, p < 0.0001) due to a very low diversity of megafauna in the SOG in shallow water. The SNK test shows that gravel habitats (GTS, GL) have a significantly higher taxonomic diversity than sand habitats (TS, SOG). There was no difference between GL and GTS, and between SOG and TS.

Principal components analysis distinguished 2 factors with eigenvalues larger than 1 that explain variability in the distribution of major taxonomic groups on the bank (Fig. 8). The first factor explains $23.5 \%$ of the variability in frequencies of occurrence of benthic taxa, while the second explains $8.8 \%$. Dissimilarity analysis had shown that combination of sediment type and depth yields the highest correlation with community structure (Fig. 9) suggesting that these two are the most important factors for the definition of habitats.

Factor 1 (Fig. 8) is related to sediment type, which is supported by highly signif- icant results of the analysis of variance $(\mathrm{df}=3 / 111, F=$ 10.8, p $<0.0001$, Cochran's $C=0.492, \mathrm{p}<0.0001$ ). The SNK test shows that the relative proportion of gravel in the sea floor sediment is responsible for the variation $(\mathrm{GL}=\mathrm{GTS}>\mathrm{SOG}=\mathrm{TS})$ (Fig. 10). High values of Factor 1 correspond to GL, and negative values correspond to sand. Asteroidea, Ascidiacea, Porifera and Brachiopoda exhibited the largest influence (highest positive loadings) on this factor. The explanatory power of principal components increased when PCA was performed on abundances of megabenthos. The first axis explained $27 \%$ and the second axis explained $15 \%$ of total variability.

Factor 2 was significantly correlated with depth $(\mathrm{r}=$ $0.34, p<0.05)$. Alternatively, values of Factor 2 may be related to hydrodynamic intensity, based on the allocation of taxa typical for low velocity current zones (e.g. deposit feeding polychaetes) in the upper part of Fig. 8 versus taxa typical for high velocity current zones (e.g. hydroids, soft corals, sea cucumbers) in the lower part.

The IKU grab samples allowed a more precise taxonomic resolution of the benthic fauna than the photographs, and qualitative information on infauna. Classi-

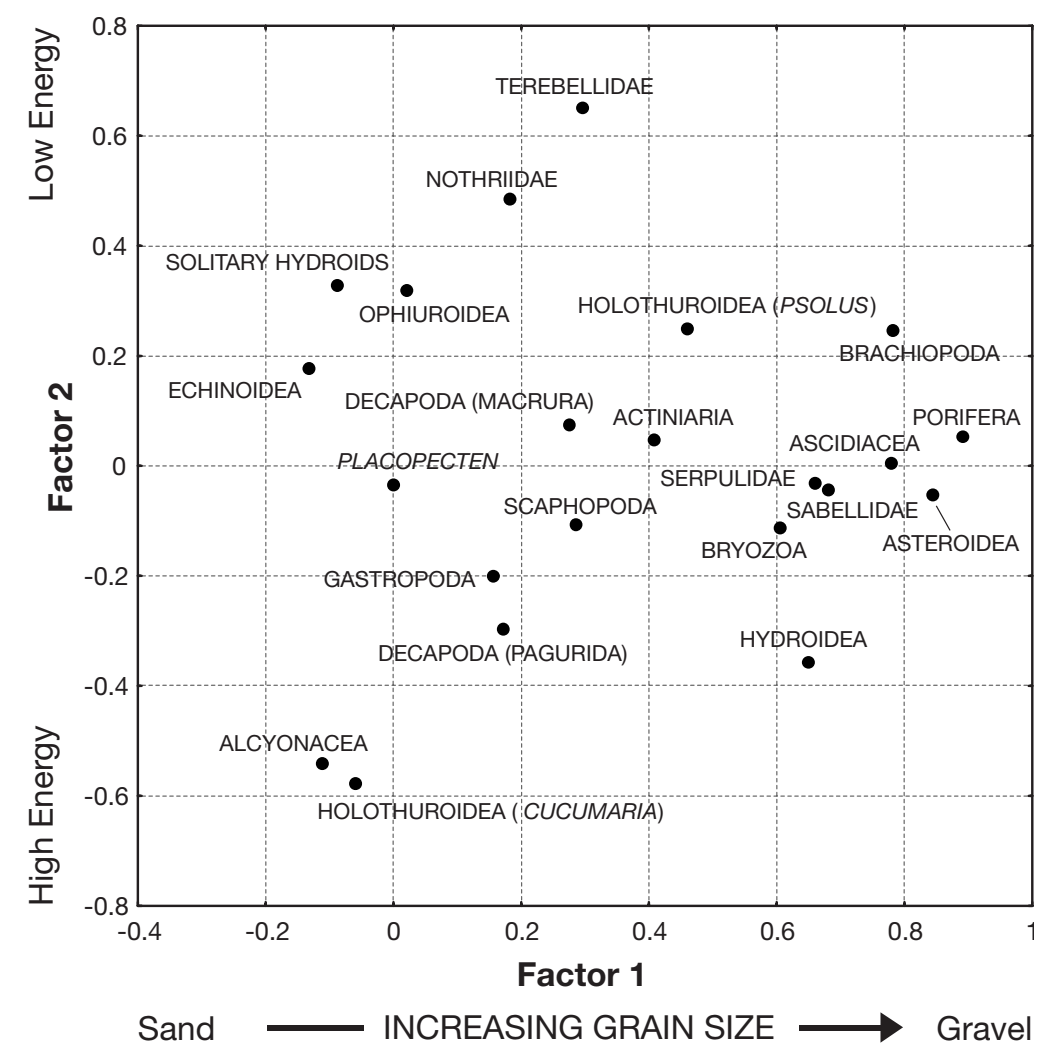

Fig. 8. Principal component analysis (PCA) of the distribution of major taxonomic groups on Browns Bank as identified from bottom photographs. The $x$-axis (Factor 1) explains variability in sediment type from sand (negative values) to gravel (positive values). The $y$-axis is related to depth and hydrodynamics 


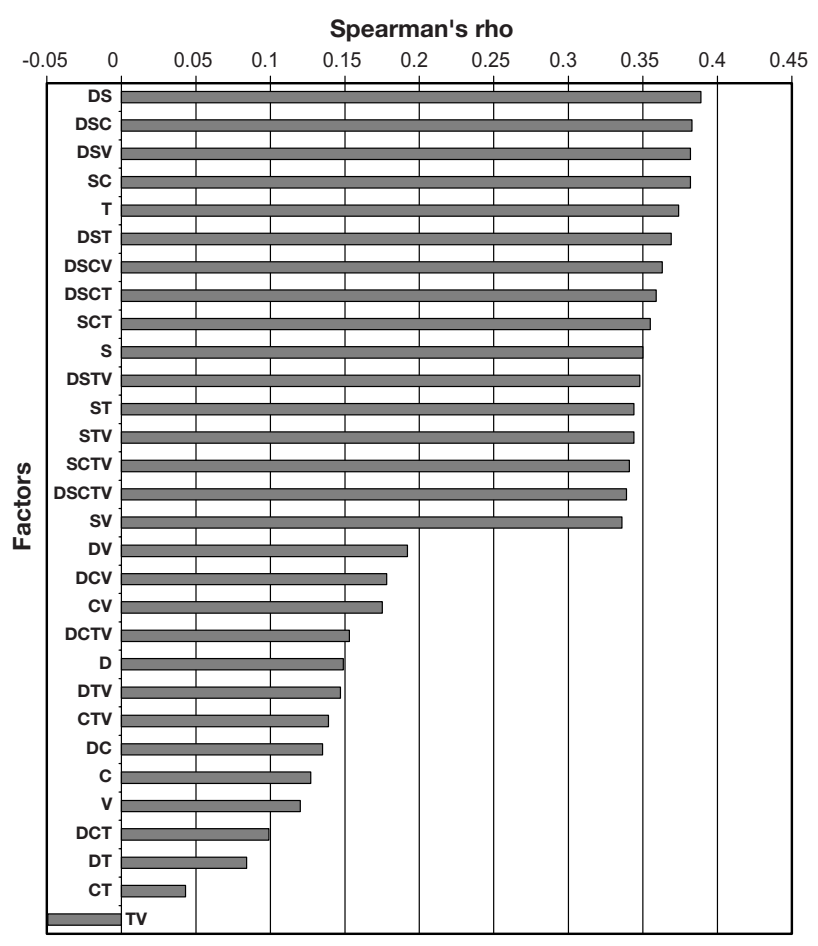

Fig. 9. Ranking of non-parametric correlations between dissimilarities among stations based on all possible combinations of physical variables and Bray-Curtis dissimilarity for benthic community data as identified from bottom photographs. D: depth, S: sediment type, C: current strength, $\mathrm{T}$ : average yearly temperature, $\mathrm{V}$ : variability in temperature based on the 4 seasons. Note that correlations become considerably higher when sediments are included in the combinations of factors

fication of this information distinguished a cluster richest in the number of species, characteristic of which were brachiopods Terebratulina septentrionalis, bryozoans Bugula sp., Caberia sp., Porella sp., polychaetes of the families Sabellidae, Serpulidae, Terebellidae and Onuphidae, and bivalve mollusks Macoma calcarea and Crenella glandula. Stations where this assemblage is common share several ubiquitous species (which may belong to different assemblages as well), such as mollusks Dentalium sp., Astarte undata and A. sulcata, and hydroids (Thuiaria sp. and Sertularella sp.). This group has a wide distribution through the whole range of samples. A cluster represented by shells of Mesodesma deauratum, Ensis sp., Spisula polynyma and sand dollars (Echinarachnius parma) occurs in SOG with shell hash.

The presence of the Emerald Silt directly beneath gravel and sand has likely influenced the presence of fine-grained material in some of the sediment samples and the distribution of benthic communities with affinity for fine-grained sediment.

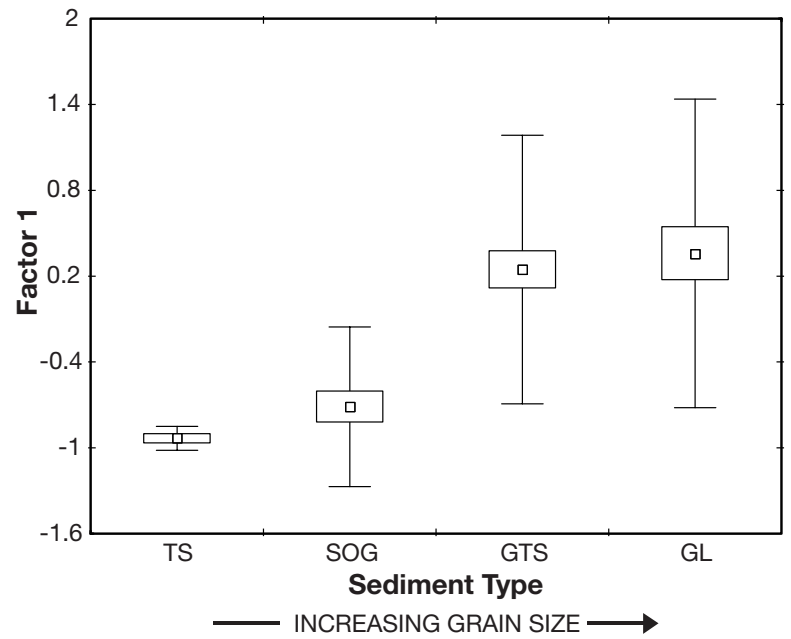

Fig. 10. Average values of Factor 1 distinguished by Principal component analysis (PCA) pertaining to different sediment types: TS, SOG, GTS and GL. See Fig. 7 legend for abbreviations. Boxes show standard deviations, and vertical error bars indicate variance

\section{Benthic habitats and species associations}

Based on the sea floor sediment map (Fig. 4) and statistical analysis of benthos, 6 habitats and corresponding associations of benthic animals were mapped (Figs 11 \& 12, Table 1). Each of the habitats is distinguished on the basis of substrate, habitat complexity, relative current strength, and water depth. The spatial allocation of samples, abundance, and commonness of species are used as additional guidelines for identification of habitat zonation. Species associations typical for each habitat are listed below.

(1) Shallow water habitat. Shallow water areas with sand substrate (TS, SOG) are characterized by a very low abundance and diversity of visible megafauna (Figs 11a \& 12, Table 1) and are high-energy environments with mobile sediment where it is difficult for epifauna to establish and proliferate. Recently deposited, medium- to coarse-grained sand can be rich in meiofauna, with poor macrofauna and almost no epifauna (Rhoads 1976). It is possible that some species of infauna, such as surf clams (Spisula solidissima) or softshelled clams (Mya truncata) are common, but are not identifiable on the photographs. Shell hash of Mesodesma deauratum was very common in grab samples from these shallow water, sand substrate sites, indicating the possibility of infauna.

(2) Deep water habitat. Low diversity and abundance of visible megafauna characterize deep water areas with sand substrate (TS, SOG) surrounding Browns Bank (Figs 11b \& 12, Table 1). Relict sands are 

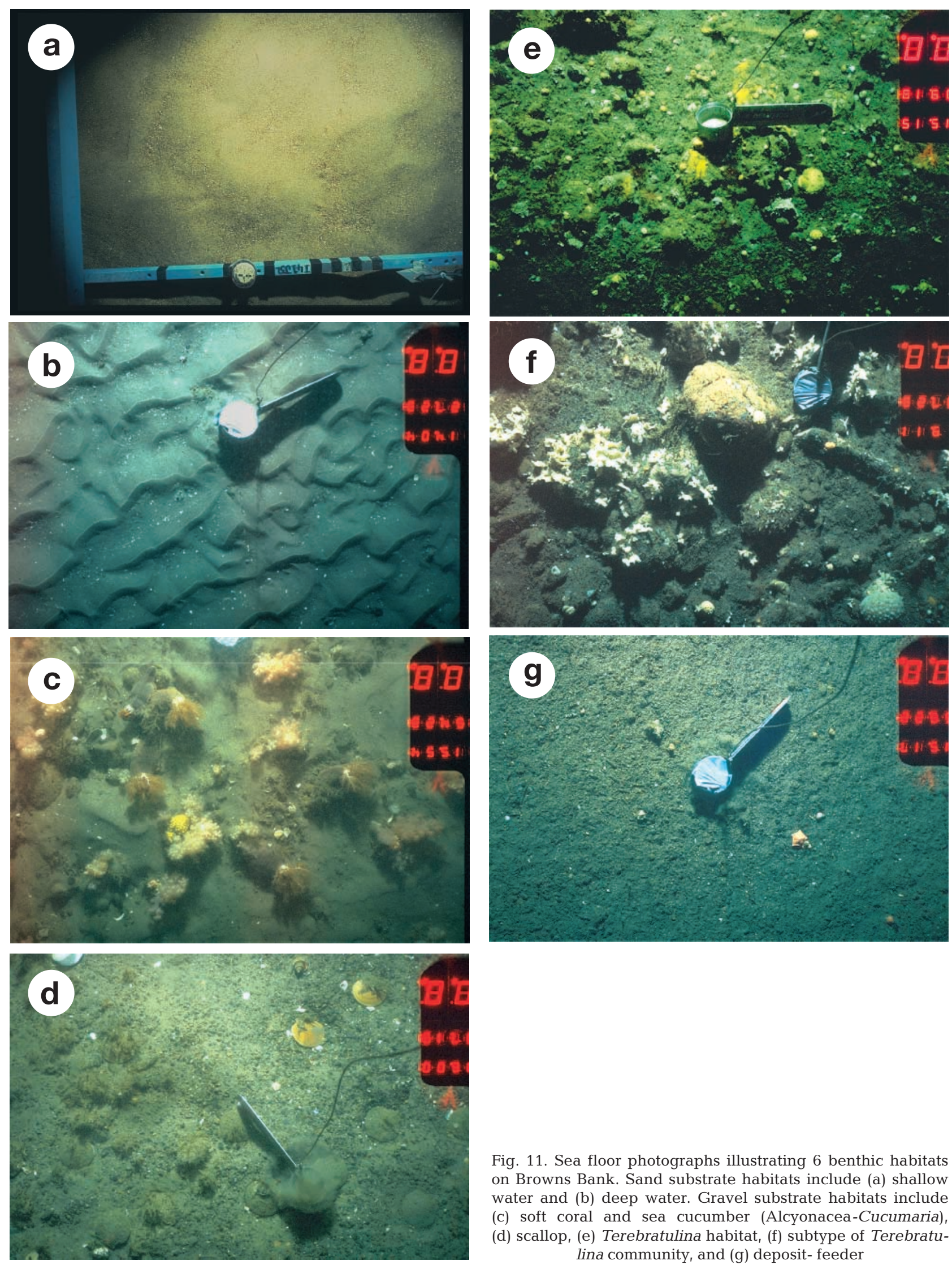

Fig. 11. Sea floor photographs illustrating 6 benthic habitats on Browns Bank. Sand substrate habitats include (a) shallow water and (b) deep water. Gravel substrate habitats include (c) soft coral and sea cucumber (Alcyonacea-Cucumaria), (d) scallop, (e) Terebratulina habitat, (f) subtype of Terebratulina community, and $(\mathrm{g})$ deposit- feeder 


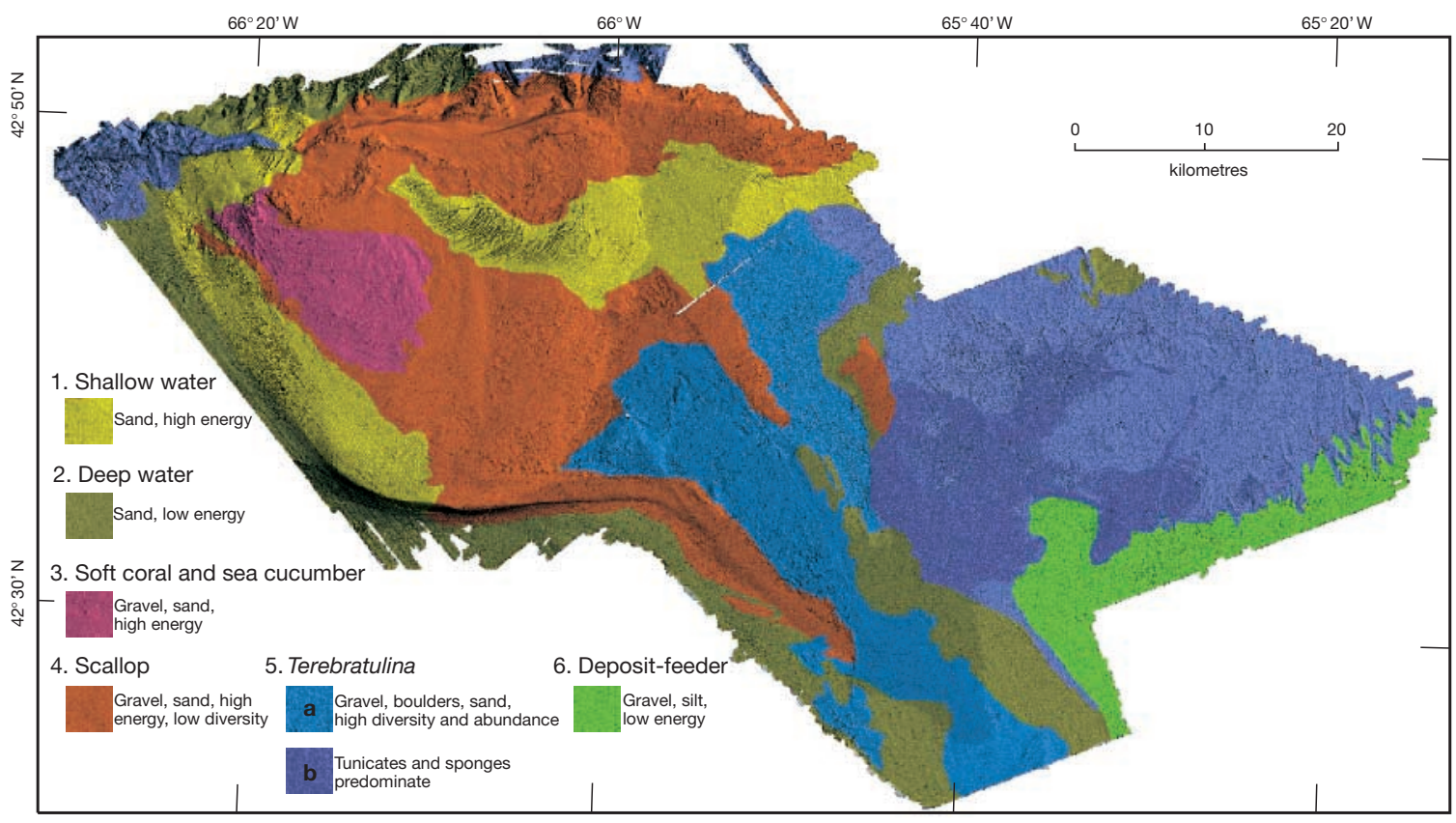

Fig. 12. Interpreted habitat map of Browns Bank. Six colour-coded benthic habitats are defined, distinguished on the basis of substrate type, benthic assemblage, habitat complexity, relative current strength and depth (Table 1). Note that 2 subtypes of Terebratulina habitat are shown

considered a more stable environment than modern sands, with less sedimentation and well-developed macrofauna (Rhoads 1976). Many broken shells of Mesodesma deauratum, sand dollars, Spisula polynyma, barnacle tests, Neptunea sp., and Chlamys islandica were found in sediment samples, suggesting that sand-dwelling fauna may be well developed. Solitary hydroids (such as Corymorpha sp.) are also common. It is noteworthy that photograph analysis indicates that these animals were present in the shallow water sand habitat during 1984-1985.

(3) Soft coral and sea cucumber (Alcyonium-Cucumaria) habitat. This habitat (Figs 11c \& 12, Table 1) occurs on gravel substrate (GL, GTS) on the western, shallow part of Browns Bank, a region dominated by strong currents. Soft corals Alcyonium digitatum and Duva multiflora and sea cucumbers Cucumaria frondosa are the most abundant (and sometimes the only) species of megafauna visible on the sea floor. Gravel patches are suitable for larval settlement (Hamel \& Mercier 1996), and juveniles may migrate or become redistributed by currents over the larger exposed areas of the bank. The presence of these large suspensionfeeders suggests that this habitat is rich in plankton and suspended organic matter. Larvae of Alcyonacea attach to gravel particles, and the adult colony can not relocate after its establishment. Therefore, the presence of soft corals among sandy patches means that there is a very thin layer of mobile sand over GL, which is corroborated by the large number of colonies evident in some photographs. Gravel patches in this area may also be suitable for scallop populations, and this habitat is difficult to distinguish from scallop habitat on the basis of sea floor sediment type. The rationale for mapping this species assemblage was its distinct spatial allocation in the western part of the bank. It is likely that the Browns Bank water circulation pattern promotes the retention of juveniles and adults of Cucumaria frondosa here.

(4) Scallop (Placopecten magellanicus) habitat. Scallops were found in highest densities on gravel substrate (GL, GTS) on the western part of Browns Bank (Figs 11d \& 12, Table 1). The presence of strong currents for larval dispersion and gravel for larval settlement (Bousfield 1960), combined with optimum shallow water depths (Miner 1950), make this area ideal for scallop recruitment. These currents also provide scallops an abundant supply of phytoplankton, which is a primary source of scallop nutrition (Cranford \& Grant 1990). In contrast, the deeper eastern part of the bank, with the presence of finer-grained sediments and possibly periodic resuspension of detritus, is less suitable for scallop recruitment and establishment of large populations. Scallop spat is highly susceptible to siltation (Dickie \& Medcof 1956), and silt can cause adult mortality, in part through the clogging of cilia on the gills, 
which reduces oxygen consumption and leads to eventual suffocation (Larsen \& Lee 1978, Cranford \& Gordon 1992). Additionally, inorganic sediment reduces the energetic quality of ingested food, thus limiting productivity of the population. The maximum densities of scallops on the bank were generally found at depths of 70 to $90 \mathrm{~m}$ on GL or GTS (Figs $6 \& 11 \mathrm{~d}$ ). The photograph analysis indicates that scallops are common along the southeastern edge of the bank as well, although in smaller quantities. This area is subjected to strong currents along the edge of the Northeast Channel, which may be the cause for better recruitment and food supply in this area. Immigration of scallop larvae from other banks is considered to be relatively low, and it is possible that the general water circulation pattern is responsible for distribution of locally spawned scallop larvae on Browns Bank (Tremblay \& Sinclair 1991) and the resulting pattern of distribution in adult populations.

The scallop habitat is generally poor in other megafauna species. Typical species associated with scallops are Hydroidea, especially Sertularella sp., which is common and often attached to scallop shells. Carnivores, such as whelks and hermit crabs, are common and probably obtain a portion of their food supply from benthic species damaged by scallop dredging. Predatory fish and crabs are known to be attracted to the scallop dredge tracks and have elsewhere been observed in tracks at densities up to 30 times higher than outside tracks (Caddy 1970).

Scallop dredging, which is a major source of disturbance for benthic populations (Gordon et al. 1998) and surficial sediments (Caddy 1970), may have a longlasting effect on scallop habitat. Our observations show that several groups of species (i.e. Filograna implexa, Corymorpha pendula, hydroids) were more widespread during 1984-1985 surveys than in 1998. These species are easily damaged by scallop dredging (Collie et al. 1996), and a reduction in their abundance may lead to disappearance of other associated species as well (Auster et al. 1996).

(5a,b) Terebratulina community habitat. Noble et al. (1976) have described a distinct subtidal community from the Bay of Fundy, represented by the widespread, conspicuous, and recurrent brachiopod Terebratulina septentrionalis. On Browns Bank, this brachiopoddominated community typically occurs on gravel substrate with boulder-sized particles (GL, GTS) in water depths of $\sim 90 \mathrm{~m}$, mainly located in the central and eastern parts of the bank (Figs 11e \& 12, Table 1). The composition of the community closely corresponds to rock-face subtype of Noble et al. (1976), with brachiopods and sponges as the best-represented taxa. This community is usually found in cool temperate marine regions of the Atlantic Ocean. Paine (1959) and Caddy
(1970) have reported this type of community in deep water. Brachiopods are common to the seston-feeders belt (Zezina 1993), which is a characteristic underwater landscape zone of the ocean. Noble et al. (1976) found sediments between boulders to be 'rich in fines', where moderate currents $\left(<50 \mathrm{~cm} \mathrm{~s}^{-1}\right)$ predominate. Similarly, on eastern Browns Bank, a thin layer of silt commonly covers the GL surface. Terebratulina sp. larvae actively seek sites with low light (cryptic), suggesting that habitats with higher complexity are likely to attract more recruitment, and thus the establishment of brachiopod populations. Additionally, Terebratulina sp. larvae have a very short planktonic period, leading to restricted dispersal, and the gregarious distribution of individuals in populations is promoted. Ascidians, which co-occur with brachiopods, have similar habitat preferences and are known to settle in cryptic habitats, such as cracks, crevices, and beneath rocks (Svane \& Young 1989). Thus, life history traits and strong control by substrate lead to patchy distribution of populations with distinct boundaries. Most of the animals in the community are suspension-feeders. Serpulid polychaetes (commonly Filograna implexa, Spirorbis sp., and less often Serpula vermicularis) were also associated with brachiopods in this habitat. The close association of sponges and sea stars distinguished by cluster analysis (Fig. 7) is due to a high abundance of spongivorous species of genus Henricia. The region occupied by the Terebratulina community may also include patches of scallop populations, mostly on GL.

A subtype of Terebratulina community (5b in Table 1, Fig. 11f) is mapped on the eastern part of the bank (Fig. 12), where silt is prevalent on the GL and which is influenced by colder near-bottom water masses. Tunicates and sponges dominate this association of species, which is similar to the sub-community described by Noble et al. (1976) and 'biogenic gravel' community of Thouzeau et al. (1991), who found that the sand and gravel sea floor from northeast Georges Bank has the highest diversity and density of species.

In addition to high diversity of epifauna, Terebratulina habitat may have well-developed infauna, due to the presence of fine-grained sediments, and a high frequency of occurrence of various bioturbation features, such as burrows, siphons and trails. Analysis of grab samples revealed that bivalves (Astarte sp., Macoma calcarea, and Clinocardium ciliatum) are common infauna in this habitat.

(6) Deposit-feeder habitat. Several stations on Browns Bank show a distinct association of species, manifested by a high abundance of tube-dwelling deposit-feeding polychaetes (Figs $11 \mathrm{~g} \& 12$, Table 1). Photograph and grain size analysis indicate that surficial sediments in these areas consist of an accumulation of silt on gravel (GL, GTS). The upper surface of the sediment is re- 
worked and densely covered with tracks of tubebuilding polychaetes (possibly Nothriidae and Terebellidae). Diversity of visible organisms is generally low, and the gravel occasionally accommodates attached anemones, brachiopods and sponges. Infauna is probably abundant, based on burrows of varying size and on traces of fish-feeding activity (numerous pits and trails on the surface of mud). In general, the deeper eastern part of the bank may be a suitable feeding area for groundfish due to dominance of deposit-feeders (Wildish et al. 1989) which are otherwise responsible for a small proportion of total production $(8.4 \%)$. The 1984-1985 sea floor photographs show that Nothriidae were present on gravel in the shallow part of the bank, in areas where shell hash provides enough material for building tubes. Abundance of tubiferous polychaetes is highest in the deeper part of the bank.

\section{DISCUSSION}

In this study we defined benthic habitats on the basis of sediment characteristics, water depth, and dominant benthic associations. This information is interpreted from multibeam, geophysical, geological, and photographic data, which is collected in a non-destructive way.

The use of bottom photographs instead of grab samples significantly enhances the speed of data analysis and allows the collection of more information with less expense. The major drawback of this approach is the lack of information about benthic infauna and associated detailed sediment stratigraphy; the presence of infauna can only be assessed on the basis of the occurrence of tubes, burrows, and other bioturbation features on the sea floor. Eighty taxa of megabenthos were distinguished from the bottom photographs and are comparable to the data provided by Thouzeau et al. (1991), who described a total of 106 species of epifaunal megabenthos on Georges Bank identified from dredge samples. However, this is only $15 \%$ of the total number of macrobenthic taxa identified by Wildish et al. $(1989,1990)$ from grab samples. Disregarding infauna may lead to undercounting of bivalves and polychaete species; these are the most diverse group on Georges Bank (Theroux \& Wigley 1998). However, even with coarse taxonomic resolution we were able to distinguish associations of species and to outline general trends and relationships between biota and sediments. Descriptions of macrofauna patterns on a family level have been deemed appropriate elsewhere (Warwick 1988, Warwick et al. 1990, Gray et al. 1992) where only negligible loss of discriminant information is shown to take place in multivariate analyses.
On Georges Bank, Thouzeau et al. (1991) described a 10-fold decrease in total megabenthos density on dunes compared to sand-shell bottoms, and an even more drastic contrast with gravel habitats. Our findings show similar patterns in regard to these extremes of sediment texture. Sediment type controls species distribution and similar groups of species commonly occur on similar substrata (Thorson 1971) where grain size is the most commonly found correlative factor (Rhoads 1976). While the relationship between sediments and biota is self-evident for many scientists, recent reviews show little evidence that sedimentary grain size alone is a primary determinant of species distribution (Snelgrove \& Butman 1994). Currents appear to play a major role in defining both sediment grain size and community structure (e.g. Jumars 1993, Wildish \& Kristmanson 1997). Newell et al. (1998) suggests that community composition is not controlled by simple granulometric properties of the sediments. They consider particle mobility at the sediment-water interface, together with a complex association of chemical and biological factors operating on a long time scale, as the most likely controlling agents.

In this study, we describe regional geomorphology and sea floor sediment texture based on interpretation of multibeam data. High-resolution representation of seabed morphology allowed the interpretation of dynamic characteristics of water masses and, furthermore, an interpretation of benthic habitats. This approach contrasts with the more traditional granulometric description, commonly based on grab samples. Our bankwide sediment description has proven to be useful for describing properties of benthic habitats. It is likely that trends in diversity, distribution, and abundance of megafauna elsewhere can be successfully predicted from the interpretation of multibeam data, which defines sedimentary habitat over a wide range of scales.

At present, it is not possible to use the interpretation of multibeam sonar data for distinguishing habitats covered by a very thin layer of silt. Such habitats, as identified by the dominance of deposit-feeders and bottom photographs, suggest higher rates of deposition and low resuspension of sediments. In such cases, as well as in the case with Alcyonacea-Cucumaria association, the benthic community provides more information about seabed habitat than sediment data. In general, sessile benthic organisms are particularly useful for habitat characterization because substrate is critical for their survival and proliferation. Being spatially fixed, they become indicative of environmental conditions of the adjacent sea floor.

The map of Browns Bank habitats (Fig. 12) is a conceptual model summarizing the present understanding of the bank ecology and represents a first attempt at integration of geological, biological, and dynamic con- 
ditions over a region. While the present model of the bank takes into account sea floor sediment and water depth, there are more factors to be considered in the future. Processes such as the transport of organic matter to the benthos, transport of sediment across the sea floor, resuspension of detritus, storm and current modification of bedforms, and a suite of processes coupling the benthic and pelagic zones should be considered in future habitat mapping projects.

Our study shows the high utility of multibeam bathymetric sonar for the interpretation of sea floor sediments and benthic habitats. Further developments of this technique should include analysis and interpretation of high-resolution seabed stratigraphy, the multibeam signal in terms of habitat complexity, and other physical properties, which may be applicable to the cross-classification of acoustic and benthic data.

Acknowledgements. We would like to thank the Masters and crews of the CCGS 'Frederick G. Creed' and the CCGS 'Hudson' for making the geoscientific data collection such a success. G. Costello of the Canadian Hydrographic Service (CHS) organized the Browns Bank multibeam bathymetric survey and provided the raw data for processing. We would like to thank G. Costello and M. Lamplugh (CHS) for their interest in all aspects of the study. D. Wildish (DFO) kindly provided sea floor photographs of Browns Bank and valuable comments for the first version of this manuscript. D. Davis (Nova Scotia Museum of Natural History) was very helpful with species identifications and general discussion of the project. D. Greenberg and J. Loder generously provided data on temperatures and current strengths. We thank C. Hannah and B. Petrie (DFO) for discussions on oceanography. This project was made possible by financial support from Clearwater Fine Foods Inc.; we thank M. Pittman and E. Roe for their interest in the work. D. C. Gordon, D. J. W. Piper, C. E. A. Carver and 3 anonymous referees improved the clarity of our thinking with their thorough reviews. Geological survey of Canada Contribution Number 2000124

\section{LITERATURE CITED}

Amos CL, King EL (1984) Bedforms of the Canadian eastern seaboard: a comparison with global occurrences. Mar Geol 57:167-208

Auster PJ, Langton RW (1999) The effects of fishing on fish habitat. Am Fish Soc Symp 22:150-187

Auster PJ, Malatesta RJ, Langton RW, Watling L, Valentine PC, Donaldson CL, Langton EW, Shepard AN, Babb I (1996) The impacts of mobile fishing gear on sea floor habitats in the Gulf of Maine (Northwest Atlantic): implications for conservation of fish populations. Rev Fish Sci 4:185-202

Begon M, Harper JL, Townsend CR (1996) Ecology: individuals, populations and communities, 3rd edn. Blackwell Science, Cambridge

Bousfield EL (1960) Canadian Atlantic sea shells. National Museum of Canada, Ottawa

Caddy JF (1970) Records of associated fauna in scallop dredge hauls from the Bay of Fundy. Fish Res Board Can Tech Rep 225
Canadian Hydrographic Service (1988) Chart L/C 8006, Scotian Shelf, Browns Bank to Emerald Bank. Scale 1:300 000, Ottawa

Clarke KR, Ainsworth M (1993) A method of linking multivariate community structure to environmental variables. Mar Ecol Prog Ser 92:205-219

Collie JS, Escanero GA, Hunke L, Valentine PC (1996) Scallop dredging on Georges Bank: photographic evaluation of effects on benthic fauna. ICES CM 1996/Mini:9

Courtney RC, Shaw J (2000) Multibeam bathymetry and backscatter imaging of the Canadian continental shelf. Geosci Can 27:31-42

Cranford PJ, Gordon DC (1992) The influence of dilute clay suspensions on sea scallop (Placopecten magellanicus) feeding activity and tissue growth. Neth J Sea Res 30: 107-120

Cranford PJ, Grant J (1990) Particle clearance and absorption of phytoplankton and detritus by the sea scallop Placopecten magellanicus (Gemelin). J Exp Mar Biol Ecol 137: 105-121

Dickie LM, Medcof JC (1956) Environment and the scallop fishery. Can Fisherman 9:7-9

Drapeau G, King LH (1972) Surficial geology of the YarmouthBrowns Bank map area. Canadian Hydrographic Service, Marine Sciences Paper 2, Geological Survey of Canada. Paper 72-24, Department of the Environment, Ottawa

Fader GBJ (1989) A Late Pleistocene low sea-level stand of the southeast Canadian offshore. In: Scott DB, Pirazzoli PA, Honig CA (eds) Late wuaternary sea-level correlation and applications. Kluwer, Dordrecht, p 71-103

Fader GBJ, King LH, MacLean B (1977) Surficial geology of the eastern Gulf of Maine and Bay of Fundy. Canadian Hydrographic Service, Marine Science Paper 19, Geological Survey of Canada, Paper 76-17, Department of Energy, Mines and Resources, Ottawa

Gordon DC, Schwinghamer P, Rowell TW, Prena J, Gilkinson K, Vass WP, McKeown DL (1998) Studies in Eastern Canada on the impact of mobile fishing gear on benthic habitat and communities. In: Dorsey EM, Pederson J (eds) Effects of fishing gear on the sea floor of New England. Massachusetts Institute of Technology, Sea Grant College Program report 98-4:63-67

Gray JS, McIntyre AD, Stirn J (1992) Manual of methods in aquatic environment research, Part 11, Biological assessment of marine pollution with particular reference to benthos. FAO Fish Tech Pap 324 FAO/UNEP, Rome

Greene HG, Yoklavich MM, Sullivan D, Cailliet GM (1995) A geophysical approach to classifying marine benthic habitats: Monterey Bay as a model. Applications of side-scan sonar and laser-line systems in fisheries research. Alaska Fish and Game Special Publication No. 9, Juneau, p 15-30

Hamel JF, Mercier A (1996) Early development, settlement, growth and spatial distribution of the sea cucumber $\mathrm{Cucu}-$ maria frondosa (Echinodermata: Holothuroidea). Can J Fish Aquat Sci 53(2):253-271

Hannah CG, Shore JA, Loder JW, Naimie CE (2000) Seasonal circulation on the western and central Scotian Shelf. J Phys Oceanogr 31:591-615

Jumars P (1993) Concepts in biological oceanography: an interdisciplinary approach. Oxford University Press, New York

King LH, Fader GBJ (1986) Wisconsinan glaciation of the continental shelf-southeast Atlantic Canada. Geol Surv Can Bull 363

King LH, MacLean B (1976) Geology of the Scotian Shelf. Canadian Hydrographic Service, Marine Sciences Paper 7, Geological Survey of Canada Paper, 74-31, Department of Energy, Mines and Resources, Ottawa 
Lancaster N (1987) Formation and reactivation of dunes in the southwestern Kalihari: paleoclimatic implications. Palaeoecol Afr 18:103-110

Larsen PF, Lee RM (1978) Observations on the abundance, distribution and growth of post-larval sea scallops Placopecten magellanicus, on Georges Bank. Nautilus 92(3): $112-116$

Lynch DR, Naimie CE (1993) The $\mathrm{M}_{2}$ tide and its residual on the outer banks of the Gulf of Maine. J Phys Oceanogr 23:2222-2253

Miner RW (1950) Field book of seashore life. Putnam and Sons, New York

Mitchell NC (1996) Processing and analysis of Simrad multibeam sonar data. In: Pratson LF, Edwards MH (eds) Advances in sea floor mapping using sidescan sonar and multibeam bathymetry data. Mar Geophys Res 18:729-739

Mitchell NC, Hughes Clarke JE (1994) Classification of sea floor geology using multibeam sonar data from the Scotian Shelf. Mar Geol 121:143-160

Mitchell NC, Somers ML (1989) Quantitative backscatter measurements with a long-range side-scan sonar. Institute of Electrical and Electronics Engineers. J Ocean Engin 14:368-374

Newell RC, Seiderer LJ, Hitchcock DR (1998) The impact of dredging works in coastal waters: a review of the sensitivity to disturbance and subsequent recovery of biological resources on the sea bed. Oceanogr Mar Biol Annu Rev 36:127-178

Noble JP, Logan A, Webb GR (1976) The recent Terebratulina community in the rocky subtidal zone of the Bay of Fundy, Canada. Lethaia 9:1-17

Page FH, Smith PC (1989) Particle drift in the surface layer off southwest Nova Scotia. Can J Fish Aquat Sci 46:21-43

Paine RT (1959) Maine records of the brachiopod Terebratulina. Maine Field Nat 15(2):46-49

Rhoads DC (1976) Organism-sediment relationships. In: McCave IN (ed) The benthic boundary layer. Plenum Press, New York

Shaw J, Courtney RC, Currie JR (1997) Marine geology of St. George's Bay, Newfoundland, as interpreted from multibeam bathymetry and back-scatter data. Geo Mar Lett 17: 188-194

Simrad (1992) SIMRAD EM 1000 Hydrographic Echo Sounder, Product Description. Simrad Subsea A/S, Horten, Norway

Smith PC (1983) The mean seasonal circulation off southwest Nova Scotia. J Phys Oceanogr 13:1034-1054

Editorial responsibility: Otto Kinne (Editor),

Oldendorf/Luhe, Germany
Snelgrove PVR, Butman CA (1994) Animal-sediment relationships revisited: cause versus effect. Oceanogr Mar Biol Annu Rev 32:111-177

Svane I, Young, CM (1989) The ecology and behavior of ascidian larvae. Oceanogr Mar Biol Annu Rev 27:45-90

Theroux RB, Wigley RL (1998) Quantitative composition and distribution of the macrobenthic invertebrate fauna of the continental shelf ecosystems of the northeastern United States. US Dept Comm, NOAA Tech Rep NMFS 140

Thorson G (1971) Life in the sea. McGraw-Hill, New York

Thouzeau GR, Robert G, Ugarte R (1991) Faunal assemblages of benthic megainvertebrates inhabiting sea scallop grounds from eastern Georges Bank, in relation to environmental factors. Mar Ecol Prog Ser 74:61-82

Todd BJ, Fader GBJ, Courtney RC, Pickrill RA (1999) Quaternary geology and surficial sediment processes, Browns Bank, Scotian Shelf, based on multibeam bathymetry. Mar Geol 162:167-216

Tremblay MJ, Sinclair M (1991) Planktonic sea scallop larvae (Placopecten magellanicus) in the Georges Bank region: broadscale distribution in relation to physical oceanography. Can J Fish Aquat Sci 49:1597-1615

Urick RJ (1983) Principles of underwater sound, 3rd edn. McGraw-Hill, New York

Warwick RM (1988) Analysis of community attributes of the macrobenthos of Frierfjord/Langesundfjord at taxonomic levels higher than species. Mar Ecol Prog Ser 46:167-170

Warwick RM, Platt HM, Clarke KR, Agard J, Gobin J (1990) Analysis of macrobenthic community structure in relation to pollution and disturbance in Hamilton Harbour, Bermuda. J Exp Mar Biol Ecol 138:119-142

Wentworth CK (1922) A scale of grade and class terms for clastic sediments. J Geol 30:377-392

Wildish DJ, Kristmanson D (1997) Benthic suspension feeders and flow. Cambridge University press, New York

Wildish DJ, Wilson AJ, Frost B (1989) Benthic macrofaunal production of Browns Bank, Northwest Atlantic. Can J Fish Aquat Sci 46:584-590

Wildish DJ, Frost B, Wilson AJ (1990) Stereographic analysis of the marine, sublittoral sediment-water interface. Can Tech Rep Fish Aquat Sci 1726

Zezina ON (1993) Brachiopods in the zone of seston-feeders on the North Atlantic slopes. In: Kuznetsov AP, Sokolova $\mathrm{MN}$ (eds) Feeding of marine invertebrates in different vertical and latitudinal zones. IORAN, Moscow, p 31-40

Submitted: April 14, 2000; Accepted: November 8, 2000

Proofs received from author(s): August 6, 2001 